\title{
Root Growth, Nutrition and Yield of Maize with Applied Finely Limestone in Surface of Cerrado Soil
}

\author{
Rafael Felippe Ratke1, Hamilton Seron Pereira², João de Deus Gomes dos Santos Junior, \\ Joaquim José Frazão4, Juliano Magalhães Barbosa ${ }^{4}$, Bruno de Oliveira Dias ${ }^{1}$ \\ ${ }^{1}$ Departamento de Engenharias, Agronomia, Campus Professora Cinobelina Elvas, Universidade Federal do \\ Piauí, Bom Jesus, Brazil \\ ${ }^{2}$ Instituto de Ciências Agrárias, Universidade Federal de Uberlândia, Uberlândia, Brazil \\ ${ }^{3}$ Embrapa, Centro Nacional de Pesquisa no Cerrado, Planaltina, Brazil \\ ${ }^{4}$ Programa de Pós-graduação em Agronomia, Universidade Federal de Goiás, Goiânia, Brazil \\ Email: rfratke@gmail.com
}

Received 6 December 2013; revised 15 February 2014; accepted 4 March 2014

Copyright (C) 2014 by authors and Scientific Research Publishing Inc.

This work is licensed under the Creative Commons Attribution International License (CC BY). http://creativecommons.org/licenses/by/4.0/

(c) (i) Open Access

\section{Abstract}

The surface applies lime to correcting soil acidity in no-tillage and promotes root development and yield of maize. However, limestone with a particle size smaller than $0.30 \mathrm{~mm}$ cannot promote this effect. The aim of this study was to determine the root attributes, nutrition and productivity of maize with limestone ground in no-tillage. The experimental design was randomized blocks with five treatments and four replications. The treatments consisted of different particle sizes of limestone applying superficially to the soil under NT 0) control, without lime, 1) $0.30 \mathrm{~mm}$ to 0.20 $\mathrm{mm} \mathrm{2)} 0.20 \mathrm{~mm}$ to $0.10 \mathrm{~mm}, 3) 0,10 \mathrm{~mm}$ to $0.05 \mathrm{~mm}$ 4) $0.05 \mathrm{~mm}$ to $0.01 \mathrm{~mm}$. Attributes root, leaf nutrition and grain yield of maize were evaluated in two years 2009 and 2010 . The elongation of roots in a $20-40 \mathrm{~cm}$ depth was greater when using limestone with particle size between $0.30 \mathrm{~mm}$ and $0.20 \mathrm{~mm}$. The root length of maize plants correlated with the levels of $\mathrm{Mn}$ in maize leaves. The root development promoted by liming effect was not reflected in the productivity of maize.

\section{Keywords}

Particle Size; No-Tillage; Limestone

\section{Introduction}

The no-tillage (NT) has power applied to the surface due to the residual untilled soil. Thus, the contact surface

How to cite this paper: Ratke, R.F., Pereira, H.S., Santos-Junior, J.D.G., Frazão, J.J., Barbosa, J.M. and Dias, B.O. (2014) Root Growth, Nutrition and Yield of Maize with Applied Finely Limestone in Surface of Cerrado Soil. American Journal of Plant Sciences, 5, 834-844. http://dx.doi.org/10.4236/ajps.2014.56097 
between soil and lime is smaller and so he presents soil residual. However, this effect is restricted to the surface layer of soil $(0-10 \mathrm{~cm})$ of disfavoring the deeper roots of the plants in the soil and absorption of water and nutrients. This finding was verified in the work of [1]-[3].

The fine roots are primarily responsible for absorbing water and nutrients by plants [4]. The evaluation of root distribution of a culture is critical for the development of rational management practices aiming at optimizing agricultural productivity [5]. Despite its role in the ecosystem and crop production, the development of these roots is poorly studied, because of the difficulty of the techniques used in their study [6].

The roots are then indicative of the efficiency of use of fertilizers and management systems in the production and development of plants. Accordingly, [7] reported that the adequacy of soil fertility and the correction of its acidity favor root development of the maize plant. Increasing the $\mathrm{pH}$ of the soil amending nutrient availability causes increases in absorption of nutrients by the maize. The application of lime in the soil in conventional tillage provides considerable increases in maize production.

Maize grown after soybeans with NT in central Brazil, contributes to the permanence of their trash in the winter due to its low $\mathrm{C}: \mathrm{N}$ ratio, favoring the soil cover, organic matter mineralization and weed control. Due to the assistance of maize with mulch, mostly planted in the second crop season, many farmers adopt this culture in the NT [8].

Limestones with particle sizes smaller than $0.30 \mathrm{~mm}$ have lower specific surface and when applied to the soil surface in NT, its particles percolate to subsurface layers, correcting soil acidity and favoring the deepening roots of this system. The objective of this work was to verify the influence of the use of limestone with a particle size smaller than $0.30 \mathrm{~mm}$ applied to the soil surface in the root attributes of maize, as well as yield and nutrient accumulation.

\section{Materials and Methods}

The experiment was conducted in October 2009, near Goiânia-GO, Brazil, located at latitude: $16^{\circ} 36^{\prime} 6$, 91" S, $^{\prime \prime}$ longitude: $49^{\circ} 16^{\prime} 57,22^{\prime \prime}$ WO. According to the Brazilian system of soil classification-SiBCS [9], the soil of this researchwas featured as dystrophic Red Oxisol. The climate as classified as tropical rainy Aw savannah, having a sub-humid climate, with two distinct seasons: a drought lasting four to five months, and a rainy season occurring from late September to April, according Köppen Climate.

The experimental design was a randomized complete block with five treatments and four replications. The treatments consisted of four limestone particle classes: 1) 0.30 to $0.20 \mathrm{~mm}$; 2) $0.200 .10 \mathrm{~mm}$; 3) 0.10 to $0.05 \mathrm{~mm}$ and 4) from 0.05 to $0.01 \mathrm{~mm}$ applied to the soil surface at a dose of $1.3 \mathrm{Mg} \cdot \mathrm{ha}^{-1}$. We used an additional treatment (control) which received no lime. The liming rate was calculated to raise the base saturation to $50 \%$, based on chemical analysis of soil $(0-20 \mathrm{~cm})$ before the experiment (Table 1). The need for liming (NC) was calculated by the base saturation: $\mathrm{CN}=(\mathrm{V} 2-\mathrm{V} 1) \times \mathrm{T} / 100$ where $\mathrm{V} 2$ is base saturation required by the crop, if we used $50 \%, \mathrm{~V} 1$ is base saturation current soil, $\mathrm{T}$ is the cations exchange capacity of the soil current total. The calculation of liming was based on the results of soil analysis before the experiment, the layer $0-20 \mathrm{~cm}$ depth.

The limestone used in the experiment was classified as dolomite extracted from metamorphic rocks, with 38\% de $\mathrm{CaO}$ and $13 \% \mathrm{MgO}$. The limestone was divided into the desired particle classes through appropriate sieves. The study soil was prepared with harrow of $12 \times 32$, or grille that has 12 discs with 32 inch, six months before the implementation of the experiment and application of different limestone particle size. The lime was applied three months before planting maize the soil surface. The different particle size limestone was application in the first year (2008).

The weeds that spread in the area were mostly Urochloadecumbens, Panicum maximum, Cenchrusechinatus, Cyperusrotundus and Commelinabenghalensis. For planting maize weeds were controlled with desiccation using 3.5 $\mathrm{L} \cdot h a^{-1}$ of glyphosate and $1 \mathrm{~L} \cdot h a^{-1} 2.4$-D spray volume of $100 \mathrm{~L} \cdot h a^{-1}$. Maize was planted on December 15,

Table 1. Analysis results of soil in the experiment area at $0-20 \mathrm{~cm}$ depth.

\begin{tabular}{|c|c|c|c|c|c|c|c|c|c|c|c|c|}
\hline $\mathrm{pH}$ & $\mathrm{Ca}^{2+}$ & $\mathrm{Mg}^{2+}$ & $\mathrm{Al}^{3+}$ & $\mathrm{H}^{+}+\mathrm{Al}^{3+}$ & $\mathrm{K}^{+}$ & CTC $^{1}$ & $\mathrm{P}$ & $\mathrm{V}^{2}$ & $\mathrm{OM}^{3}$ & SAND & SILT & CLAY \\
\hline$\left(\mathrm{H}_{2} \mathrm{O}\right)$ & \multicolumn{6}{|c|}{ cmolc $\cdot \mathrm{dm}^{-3}$} & $\mathrm{mg} \cdot \mathrm{dm}^{-3}$ & $\%$ & & & $\mathrm{~g} \cdot \mathrm{kg}^{-1}$ & \\
\hline 5.8 & 0.6 & 0.5 & 0.2 & 3.9 & 0.19 & 5.2 & 1.7 & 25.0 & 20.0 & 370.0 & 175.0 & 455.0 \\
\hline
\end{tabular}

1. Cationexchangecapacity; 2. Base saturation. 3. OrganicMatter. 
2008, in the first season 2008/2009 and on December 23, 2009 in the second season 2009/2010. The hydride was used 30A04 YieldGuard of Pioneer with spacing of $0.90 \mathrm{~m}$ with a population of 6 plants per meter. Maize received planting fertilization with $350 \mathrm{~kg} \cdot \mathrm{ha}^{-1}$ of fertilizer formulated $08-28-20$ (N, P and $\mathrm{K}$ ) with $1.5 \%$ micronutrients (B and Zn). Fertilization with $\mathrm{N}$ was done 30 days after planting maize where it was used $100 \mathrm{~kg} \cdot \mathrm{ha}^{-1}$ urea agricultural manually applied along the line of planting maize. Maizewas conducted by applying cultivation as the emergence of weeds, pests and crop diseases.

Assessments of the effect of the application of different particle size of limestone were made in couple year (crop 2008/2009 and 2009/2010). Soil sampling along with the roots was done with auger type "mug" tailored with $9.8 \mathrm{~cm}$ internal diameter and $60 \mathrm{~cm}$ in length, divided into a range of $10 \mathrm{~cm}$ to adjust the depth of the desired sample with a rod to facilitate the movement and force application. This method of root sampling was adapted from [10]. The auger has at its end a series of sharp edges, like a mountain, that aids in cutting the roots and the penetration of the equipment to the ground. The auger used was made of stainless steel and the iron rod. For every $10 \mathrm{~cm}$ depth have the ability to sample $754 \mathrm{~cm}^{3}$ soil with roots. This sampling was done at $0-10 \mathrm{~cm}$, $10-20 \mathrm{~cm}$ and $20-40 \mathrm{~cm}$ soil depth in two samples per plot in two years, 2009 and 2010. Samples were always collected at flowering maize (phenological stage R1).

The procedure to remove a sample of soil with roots began with the choice of the sampling area must be homogeneous with the crop of maize, excluding areas affected by pests and diseases, plants uneven, nests, holes, etc. The auger was stuck into the ground so that it is close to the stems of maize, sectioning different desired depths. A maize plant was removed with the aid of a knife severing its stem near the ground, to facilitate removal of soil sample roots.

Samples destructive roots with soil were stored in plastic bags with proper identification. Plastic bags used possessed great strength to hold the weight of the soil. The samples were weighed on a precision balance before the separation of the roots in the soil, thus is the weight of the soil to the roots. A small sample was collected $100 \mathrm{~g}$ of the sample with destructive to ground roots to determine the water content in soil and deducted from it afterwards. These samples were stored in cold storage for a period of one month with temperatures below $-5^{\circ} \mathrm{C}$ for subsequent separation of roots and soil. The separation of roots from the soil was carried out in the shortest possible time from the extraction field, avoiding losses of dry mass or dehydration of the roots.

For obtaining the roots requires two steps that were consistent in the use of water to remove soil and other inert materials. The first step separated the roots from the soil with the aid of water. The second stage separated from the roots and other organic materials roots of the plant that are not of interest. In this first step, it was necessary to use a bucket for sample dispersion and deposition of soil in the roots with water. Then passes its contents in a ABNT 35 (500 micron mesh) by applying water to remove soil. To facilitate this, we used a round table made of plastic with holes of the same size sieves. This procedure was repeated four times to remove as much of the soil, avoiding any loss of roots.

After this separation, we collected waste (organic material and roots) retained in the sieve, and they were placed in labeled plastic bags for the process procedure. The waste collected were keptrefrigerated in a cold chamber at $-5^{\circ} \mathrm{C}$, proceed to the next wash. A second separation of roots occurred in the shortest time possible to avoid the presence of fungi in the roots as aresult of moisture.

The washing process of the second sample was used to remove impurities which were as stones, coal, straw and small roots undesirable. These materials could hinder the process of image acquisition thus increasing source of error, especially in root weight. The second washing process was initiated with the deposition of the sample in the plastic bag in a container with water. After this, separate the roots of the impurities. Water helps remove the impurities that are stuck together the roots. We used a white container and shallow for better visualization of impurities. This procedure was repeated twice to obtain a sample without impurities, preventing loss of roots.

The digitization of maize roots separated from the soil was taken with the aid of the glass sheets of A4 size $(21 \mathrm{~cm} \times 29.7 \mathrm{~cm}$ ) with $2 \mathrm{~mm}$ thickness without side edges. In this blade, is placed a transparent tape $2 \mathrm{~cm}$ long and $2 \mathrm{~cm}$ wide reference range for scanning the roots. Separate the roots were placed on paper towel to remove excess water may affect the scanning of the roots. The dried roots were separated and placed on glass slides, arranged in the vertical direction without overlapping, for subsequent scanning. The process of image acquisition roots was done by digitizing the same previously prepared with the use of a scanner table of appropriate size (with ability to scan an entire A4 sheet). The scanner was configured to capture images with a resolution of 300 DPI, with scanning in grayscale. The scan provided images with contrast, the roots black on a white background, 
for this was placed a sheet of blank paper and a transparency in the wall scanner. The scanner used in this study was the brand Genius model HR8.

The images acquired from maize roots were saved with the file extension type bitmap for further analysis in computer application SIARCS $3.0^{\circledR}$ [11]. The digitized roots were placed in paper bags identified weighed to obtain fresh weight of the roots. These roots were placed in greenhouses forced ventilation for 72 hours at $60^{\circ} \mathrm{C}$ and then weighed to obtain their dry mass. The glass sheet size $21 \mathrm{~cm} \times 29.7 \mathrm{~cm}$, in some cases, the sampled root volume does not contain all of the roots. Thus, subsamples were taken and separated from the roots scanned. The subsamples of roots through the same process of roots scanned to obtain their green mass and dry mass. So, the end of the analysis process area and root length corrections were made based on the subsample to calculate its volume, area and length volume and mass of soil sampled.

The data area, length and root mass of maize were used to generate the following attributes depending on the root volume and mass of dry soil sampled: The root area due to the volume of soil sampled (ARV), the root area due the mass of soil sampled (ARM), root length due to the volume of soil sampled (CRV), root length depending on the weight of the sampled soil (CRM), the root mass as a function of the volume of soil sampled (MRV) the root mass as a function of the mass of soil sampled (MRS), root length as a function of root mass by the mass of soil sampled (CREM). The CREM refers to the diameter of the roots in the soil, the larger the relative length of the root mass, the smaller the diameter of these roots.

The nutrition of the plants was assessed from samples collected from maize leaves every season done. Leaf sampling was carried out in the maize when $50 \%$ to $75 \%$ of the crop had the female inflorescence, collecting below and opposite to the first spike, discarding the midrib, ten plants per plot. At the laboratory samples obtained were analyzed for the determination of macronutrients ( $\mathrm{Ca}$ and $\mathrm{Mg}$ ) and micronutrients $(\mathrm{Cu}, \mathrm{Fe}, \mathrm{Mn}$ and Zn) using the methodology described by [12].

The plotwere harvested inside a useful plot of $20 \mathrm{~m}^{2}$ on 15/04/2009 and on 25/04/2010 representing maize production in 2009 and 2010 respectively. These plot were threshed grain and maize were weighed correcting the grain moisture to $13 \%$. Thegrain yield of maize extrapolated to Megagram per hectare.

The data were statistically analyzed using the computer application SAS [13]. Data were analyzed by applying the $\mathrm{F}$ test in analysis of variance and means were compared by Tukey test $(\alpha=0.05)$. We performed the correlation of root attributes maize with chemical soil with foliar and production of this crop.

To evaluate the attributes of maize root area and length as two samples were collected per plot. Thus, considering the number of repetitions of 24 samples of maize roots per treatment were used. The results of root attributes of maize this study were submitted to the normality. When this data was not normal applied the methodology proposed by [14] to classify the coefficient of variation (CV) of these attributes. The classification of CV has shown how the study methodology was efficient to root.

\section{Results and Discussion}

The highest specific root length per root mass (CREM) maize was found with surface application of limestone with a particle size between $0.30 \mathrm{~mm}$ and $0.20 \mathrm{~mm}$ in $20-40 \mathrm{~cm}$ layer of soil in the first year (Table 2). The use of limestone with particles smaller than $0.20 \mathrm{~mm}$ applied to the soil surface was not efficient to improve root development of maize plants that first year.

The root length in the soil surface was higher with the use of limestone with 84\% PRNT applied to the surface layer of soil in 10 to $20 \mathrm{~cm}$ of soil in maize. Already the average radius of maize roots was not modified by liming, these attributes are related to root the presence of $\mathrm{Ca}$ and $\mathrm{Al}$ in the soil, which restricted the exploitation of roots in the topsoil [7]. Accordingly, these results disagree with the present work, where with limestone ground maize roots lengthened in the soil profile.

The highest values of maize CREM layer $10-20 \mathrm{~cm}$ soil depth was found with the use of limestone with a particle size between $0.10 \mathrm{~mm}$ to $0.05 \mathrm{~mm}$ in the second year (2010). Already in the $20-40 \mathrm{~cm}$, the limestone with grain size between $0.30 \mathrm{~mm}$ to $0.20 \mathrm{~mm}$ promoted greater CRV maize (Table 3). Thus, the use of limestone with large particles improved the deepening of maize roots in the soil profile.

Results developing maize roots evaluated by their attributes of root length and root mass showed probability distribution that deviated from normal in the two years of study. However, the classification of CV proposed by [14] was utilized to verify the efficiency of this variability data.

In 2009, the CV values were low for ARV and ARM maize at a depth of $0-10 \mathrm{~cm}, 10-20 \mathrm{~cm}$ in depth. The 
Table 2. Average values of attributes root of maize with application different particle size of limestone, in three soil depths (0 - $10 \mathrm{~cm}, 10-20 \mathrm{~cm}$ and $20-30 \mathrm{~cm})$. Year: 2009.

\begin{tabular}{|c|c|c|c|c|c|c|c|c|c|c|c|c|c|c|}
\hline Particles Size & $\mathbf{A R V}^{1}$ & & ARM & & CRV & & CRM & & MRV & & MRS & \multicolumn{3}{|c|}{ CREM } \\
\hline$(\mathrm{mm})$ & $\mathrm{cm}^{2} \cdot \mathbf{d m}^{-3}$ & & $\mathrm{~cm}^{2} \cdot \mathrm{kg}^{-1}$ & & $\mathbf{c m} \cdot \mathbf{d m}^{-3}$ & & $\mathrm{~cm} \cdot \mathrm{kg}^{-1}$ & & $\mathbf{g} \cdot \mathbf{d m}^{-3}$ & & $\mathbf{g} \cdot \mathbf{k g}^{-1}$ & \multicolumn{3}{|c|}{$\mathrm{cm} \cdot \mathrm{g}^{-1} \cdot \mathrm{kg}^{-1}$} \\
\hline & \multicolumn{14}{|c|}{$0-10 \mathrm{~cm}$} \\
\hline Control & 114.25 & $a^{2}$ & 97.12 & a & 1367.97 & $\mathrm{a}$ & 872.13 & $\mathrm{a}$ & 3.06 & $\mathrm{a}$ & 2.60 & $\mathrm{a}$ & 453.27 & $\mathrm{a}$ \\
\hline $0.30-0.20$ & 125.48 & a & 96.33 & a & 1562.35 & $\mathrm{a}$ & 899.58 & $\mathrm{a}$ & 4.12 & $\mathrm{a}$ & 3.16 & $\mathrm{a}$ & 398.65 & $\mathrm{a}$ \\
\hline $0.20-0.10$ & 158.60 & $\mathrm{a}$ & 130.06 & $\mathrm{a}$ & 1616.93 & $\mathrm{a}$ & 994.43 & $\mathrm{a}$ & 3.87 & $\mathrm{a}$ & 3.17 & $\mathrm{a}$ & 391.13 & $\mathrm{a}$ \\
\hline $0.10-0.05$ & 93.46 & $\mathrm{a}$ & 73.43 & a & 1192.67 & $\mathrm{a}$ & 702.77 & $\mathrm{a}$ & 2.86 & $\mathrm{a}$ & 2.25 & $\mathrm{a}$ & 404.22 & $\mathrm{a}$ \\
\hline $0.05-0.01$ & 135.75 & $\mathrm{a}$ & 104.88 & $\mathrm{a}$ & 1555.76 & $\mathrm{a}$ & 901.46 & $\mathrm{a}$ & 3.31 & $\mathrm{a}$ & 2.56 & $\mathrm{a}$ & 206.10 & $\mathrm{a}$ \\
\hline Average & 125.51 & & 100.36 & & 1459.13 & & 874.07 & & 3.44 & & 2.75 & & 370.67 & \\
\hline CV (\%) & 61.35 & & 22.71 & & 46.72 & & 24.24 & & 36.02 & & 36.21 & & 57.71 & \\
\hline \multirow[t]{2}{*}{ CV ranks } & low & & low & & low & & low & & high & & high & & low & \\
\hline & \multicolumn{14}{|c|}{$10-20 \mathrm{~cm}$} \\
\hline Control & 41.24 & a & 32.14 & $\mathrm{a}$ & 624.82 & $\mathrm{a}$ & 365.23 & $\mathrm{a}$ & 1.27 & $\mathrm{a}$ & 0.99 & $\mathrm{a}$ & 361.16 & $\mathrm{a}$ \\
\hline $0.30-0.20$ & 74.08 & $\mathrm{a}$ & 53.35 & $\mathrm{a}$ & 702.71 & $\mathrm{a}$ & 379.51 & $\mathrm{a}$ & 1.52 & $\mathrm{a}$ & 1.09 & $\mathrm{a}$ & 331.48 & $\mathrm{a}$ \\
\hline $0.20-0.10$ & 41.90 & $\mathrm{a}$ & 31.16 & $\mathrm{a}$ & 552.09 & $\mathrm{a}$ & 307.94 & $\mathrm{a}$ & 1.29 & $\mathrm{a}$ & 0.96 & $\mathrm{a}$ & 324.71 & $\mathrm{a}$ \\
\hline $0.10-0.05$ & 44.92 & $\mathrm{a}$ & 33.08 & $\mathrm{a}$ & 520.36 & $\mathrm{a}$ & 287.39 & $\mathrm{a}$ & 1.18 & $\mathrm{a}$ & 0.87 & $\mathrm{a}$ & 332.77 & $\mathrm{a}$ \\
\hline $0.05-0.01$ & 55.33 & $\mathrm{a}$ & 41.69 & $\mathrm{a}$ & 770.23 & $\mathrm{a}$ & 435.26 & $\mathrm{a}$ & 1.55 & $\mathrm{a}$ & 1.17 & $\mathrm{a}$ & 350.42 & $\mathrm{a}$ \\
\hline Average & 51.50 & & 38.28 & & 634.04 & & 355.07 & & 1.36 & & 1.02 & & 340.11 & \\
\hline CV (\%) & 61.68 & & 31.58 & & 52.31 & & 26.13 & & 29.36 & & 29.47 & & 27.75 & \\
\hline \multirow[t]{2}{*}{ CV ranks } & \multicolumn{2}{|l|}{ low } & \multicolumn{2}{|l|}{ medium } & \multicolumn{2}{|l|}{ low } & \multicolumn{2}{|l|}{ low } & \multicolumn{2}{|l|}{ high } & \multicolumn{2}{|l|}{ high } & \multicolumn{2}{|l|}{ low } \\
\hline & & & & & & & $20-40 \mathrm{~cm}$ & & & & & & & \\
\hline Control & 7.29 & a & 5.19 & $\mathrm{a}$ & 139.24 & $\mathrm{a}$ & 149.66 & $\mathrm{a}$ & 0.42 & $\mathrm{a}$ & 0.30 & $\mathrm{a}$ & 496.32 & $\mathrm{~b}$ \\
\hline $0.30-0.20$ & 36.22 & $\mathrm{a}$ & 28.28 & $\mathrm{a}$ & 432.23 & $\mathrm{a}$ & 508.82 & $\mathrm{a}$ & 0.67 & $\mathrm{a}$ & 0.53 & $\mathrm{a}$ & 858.18 & $\mathrm{a}$ \\
\hline $0.20-0.10$ & 7.33 & $\mathrm{a}$ & 5.57 & $\mathrm{a}$ & 123.32 & $\mathrm{a}$ & 141.43 & $\mathrm{a}$ & 0.42 & $\mathrm{a}$ & 0.32 & $\mathrm{a}$ & 435.00 & $\mathrm{~b}$ \\
\hline $0.10-0.05$ & 9.72 & a & 7.58 & $\mathrm{a}$ & 170.35 & $\mathrm{a}$ & 200.21 & $\mathrm{a}$ & 0.45 & $\mathrm{a}$ & 0.35 & $\mathrm{a}$ & 581.79 & $\mathrm{~b}$ \\
\hline $0.05-0.01$ & 15.09 & $\mathrm{a}$ & 12.25 & $\mathrm{a}$ & 225.63 & $\mathrm{a}$ & 276.23 & $\mathrm{a}$ & 0.59 & $\mathrm{a}$ & 0.48 & $\mathrm{a}$ & 514.81 & $\mathrm{~b}$ \\
\hline Average & 15.13 & & 11.77 & & 218.16 & & 255.27 & & 0.51 & & 0.39 & & 577.22 & \\
\hline CV (\%) & 86.77 & & 32.02 & & 63.63 & & 27.51 & & 39.89 & & 41.07 & & 32.53 & \\
\hline CV ranks & high & & high & & low & & low & & high & & high & & low & \\
\hline
\end{tabular}

${ }^{1}$ ARV—root area based on the volume of soil sampled; ARM—root area based on soil mass sampled; CRV—root length based on the volume of soil sampled; CRM — root length based on mass sampled soil; MRV—root mass based on the volume of soil sampled; MRS—dry root mass-based soil sampled; CREM - root length per root mass based on the mass of the sampled soil; ${ }^{2}$ Values followed by lower case letters in the same column do not differ (Tukey test, $\mathrm{P}<0.05$ ); ${ }^{3} \mathrm{CV}$ (\%): Coefficient of variation. ${ }^{4} \mathrm{CV}$ ranks: Coefficient of variation classification proposed by [14].

RSD values was low and medium ARV for ARM maize, this CV values were higher in the 20 - $40 \mathrm{~cm}$ soil layer. the root attributes CRV, CRM and CREMhad low CV values in all soil depths. The average results of MRV and MRS at high CV values in all soil layers. However, the results of maize root attributes using lime applied to the soil surface varied considerably. Therefore, the root attributes that are related to root length showed low variability for classification of CV [14], showing that the method of the auger can be used to describe this root parameter. 
Table 3. Average values of attributes root of maize with application different particle size of limestone, in three soil depths (0 - $10 \mathrm{~cm}, 10-20 \mathrm{~cm}$ and $20-30 \mathrm{~cm})$. Year: 2010.

\begin{tabular}{|c|c|c|c|c|c|c|c|c|c|c|c|c|c|c|}
\hline Particles Size & ARV & & ARM & & CRV & & CRM & & MRV & & MRS & \multicolumn{3}{|c|}{ CREM } \\
\hline \multirow[t]{2}{*}{ (mm) } & $\mathrm{cm}^{2} \cdot \mathrm{dm}^{-3}$ & & $\mathrm{~cm}^{2} \cdot \mathbf{k g}^{-1}$ & & $\mathbf{c m} \cdot \mathbf{d m}^{-3}$ & & $\mathbf{c m} \cdot \mathbf{k g}^{-1}$ & & $\mathrm{~g} \cdot \mathrm{dm}^{-3}$ & & $\mathbf{g} \cdot \mathbf{k g}^{-1}$ & & $\mathrm{~cm} \cdot \mathrm{g}^{-1} \cdot \mathrm{kg}^{-1}$ & \\
\hline & \multicolumn{14}{|c|}{$0-10 \mathrm{~cm}$} \\
\hline Control & 97.08 & a & 64.49 & $\mathrm{a}$ & 741.10 & $\mathrm{a}$ & 494.11 & $\mathrm{a}$ & 6.31 & $\mathrm{a}$ & 4.39 & $\mathrm{a}$ & 124.30 & $\mathrm{a}$ \\
\hline $0.30-0.20$ & 185.92 & $\mathrm{a}$ & 152.07 & $\mathrm{a}$ & 1448.52 & $\mathrm{a}$ & 1185.08 & $\mathrm{a}$ & 6.35 & $\mathrm{a}$ & 4.22 & $\mathrm{a}$ & 194.37 & $\mathrm{a}$ \\
\hline $0.20-0.10$ & 85.73 & a & 80.46 & $\mathrm{a}$ & 756.95 & $\mathrm{a}$ & 676.32 & $\mathrm{a}$ & 4.07 & $\mathrm{a}$ & 3.81 & $\mathrm{a}$ & 139.93 & $\mathrm{a}$ \\
\hline $0.10-0.05$ & 269.15 & $\mathrm{a}$ & 233.82 & $\mathrm{a}$ & 2726.22 & $\mathrm{a}$ & 2404.31 & $\mathrm{a}$ & 6.36 & $\mathrm{a}$ & 4.81 & a & 331.34 & $\mathrm{a}$ \\
\hline $0.05-0.01$ & 143.75 & a & 150.93 & $\mathrm{a}$ & 948.67 & $\mathrm{a}$ & 984.79 & $\mathrm{a}$ & 5.48 & $\mathrm{a}$ & 5.35 & $\mathrm{a}$ & 173.43 & $\mathrm{a}$ \\
\hline Average & 156.33 & & 136.35 & & 1324.29 & & 1148.92 & & 5.72 & & 4.52 & & 192.67 & \\
\hline CV (\%) & 122.96 & & 130.44 & & 133.15 & & 139.03 & & 9.19 & & 26.46 & & 111.29 & \\
\hline \multirow[t]{2}{*}{ CV ranks } & \multicolumn{2}{|l|}{ high } & \multicolumn{2}{|l|}{ high } & \multicolumn{2}{|l|}{ high } & \multicolumn{2}{|c|}{ medium } & \multicolumn{2}{|l|}{ high } & \multicolumn{2}{|l|}{ high } & \multicolumn{2}{|l|}{ high } \\
\hline & \multicolumn{14}{|c|}{$10-20 \mathrm{~cm}$} \\
\hline Control & 114.38 & a & 106.06 & $\mathrm{a}$ & 954.65 & $\mathrm{a}$ & 846.36 & $\mathrm{a}$ & 4.78 & $\mathrm{a}$ & 4.13 & a & 173.84 & $a b$ \\
\hline $0.30-0.20$ & 137.80 & $\mathrm{a}$ & 121.65 & $\mathrm{a}$ & 1267.25 & $\mathrm{a}$ & 1130.22 & a & 3.74 & $\mathrm{a}$ & 3.14 & a & 122.93 & $\mathrm{~b}$ \\
\hline $0.20-0.10$ & 169.37 & $\mathrm{a}$ & 144.58 & $\mathrm{a}$ & 1115.53 & $\mathrm{a}$ & 937.40 & $\mathrm{a}$ & 3.92 & $\mathrm{a}$ & 2.76 & $\mathrm{a}$ & 147.22 & $\mathrm{~b}$ \\
\hline $0.10-0.05$ & 256.30 & $\mathrm{a}$ & 208.94 & $\mathrm{a}$ & 2487.28 & $\mathrm{a}$ & 2062.34 & $\mathrm{a}$ & 3.80 & $\mathrm{a}$ & 3.11 & a & 355.39 & $\mathrm{a}$ \\
\hline $0.05-0.01$ & 171.47 & $\mathrm{a}$ & 151.00 & $\mathrm{a}$ & 1321.87 & $\mathrm{a}$ & 1164.18 & $\mathrm{a}$ & 4.91 & $\mathrm{a}$ & 4.18 & $\mathrm{a}$ & 243.24 & $\mathrm{ab}$ \\
\hline Average & 169.86 & & 146.45 & & 1429.32 & & 1228.10 & & 4.23 & & 3.47 & & 208.52 & \\
\hline CV (\%) & 72.20 & & 84.67 & & 85.09 & & 91.58 & & 33.17 & & 41.76 & & 75.04 & \\
\hline \multirow[t]{2}{*}{ CV ranks } & \multicolumn{2}{|l|}{ high } & \multicolumn{2}{|l|}{ high } & \multicolumn{2}{|l|}{ low } & \multicolumn{2}{|l|}{ low } & \multicolumn{2}{|l|}{ high } & \multicolumn{2}{|l|}{ high } & \multicolumn{2}{|l|}{ high } \\
\hline & \multicolumn{14}{|c|}{$20-40 \mathrm{~cm}$} \\
\hline Controle & 16.92 & a & 12.00 & $\mathrm{a}$ & 153.02 & $\mathrm{a}$ & 110.59 & $\mathrm{ab}$ & 2.02 & $\mathrm{a}$ & 1.67 & $\mathrm{a}$ & 59.06 & $\mathrm{a}$ \\
\hline $0.30-0.20$ & 64.11 & $\mathrm{a}$ & 115.71 & $\mathrm{a}$ & 624.26 & a & 1127.31 & $\mathrm{a}$ & 2.49 & $\mathrm{a}$ & 3.24 & a & 198.55 & $\mathrm{a}$ \\
\hline $0.20-0.10$ & 37.43 & $\mathrm{a}$ & 31.73 & $\mathrm{a}$ & 368.30 & $\mathrm{a}$ & 319.14 & $\mathrm{ab}$ & 2.00 & $\mathrm{a}$ & 2.03 & a & 102.16 & $\mathrm{a}$ \\
\hline $0.10-0.05$ & 57.44 & a & 55.46 & $\mathrm{a}$ & 509.35 & $\mathrm{a}$ & 515.91 & $\mathrm{ab}$ & 2.14 & $\mathrm{a}$ & 2.57 & a & 167.08 & a \\
\hline $0.05-0.01$ & 37.91 & a & 44.52 & $\mathrm{a}$ & 422.89 & $\mathrm{a}$ & 493.43 & $\mathrm{~b}$ & 2.06 & $\mathrm{a}$ & 2.71 & a & 103.25 & $\mathrm{a}$ \\
\hline Average & 42.76 & & 51.88 & & 415.56 & & 513.27 & & 2.14 & & 2.44 & & 126.02 & \\
\hline CV (\%) & 69.21 & & 111.68 & & 62.78 & & 108.74 & & 30.15 & & 57.61 & & 81.47 & \\
\hline CV ranks & high & & high & & low & & low & & high & & high & & high & \\
\hline
\end{tabular}

${ }^{1} \mathrm{ARV}$ — root area based on the volume of soil sampled; ARM—root area based on soil mass sampled; CRV—root length based on the volume of soil sampled; CRM — root length based on mass sampled soil; MRV—root mass based on the volume of soil sampled; MRS — dry root mass-based soil sampled; CREM - root length per root mass based on the mass of the sampled soil; ${ }^{2}$ Values followed by lower case letters in the same column do not differ (Tukey test, $\mathrm{P}<0.05) ;{ }^{3} \mathrm{CV}(\%)$ : Coefficient of variation. ${ }^{4} \mathrm{CV}$ ranks: Coefficient of variation classification proposed by [14].

The root mass, the auger method showed high CV values which may not reflect the reality of the root growth of maize through the use of limestone, due to the large variability in the data. However, it was essential that all parameters of roots were observed to generate the CREM attribute, which found that the use of limestone incorporated into the soil with a particle size greater than $0.30 \mathrm{~mm}$ favored root development of maize in the $20-40$ cm layer soil. 
In 2010, the CV values were high for ARV, ARM, MRV, MRS and CREV maize in all different depths of soil sampled. However, the CV values were for CRV and CRV at a depth of $0-10 \mathrm{~cm}$ soil, and these values were low at depths of $10-20$ and $20-40 \mathrm{~cm}$. Therefore, the variability of results of the root attributes are large. Thus, for root length in relation to the volume and mass of soil these values were low, so even with great variability after limestone with different particle sizes on the surface of soils modified maize root development.

The root length of maize by soil surface to a depth of $40 \mathrm{~cm}$, both in the row and between the lines was not significantly altered by surface application of lime [15]. Therefore, agreeing with this research, the grainy lime applied to the soil surface modified the maize root development in the soil profile, improving the deepening roots in layer 20 - $40 \mathrm{~cm}$ soil.

The $40 \%$ of root length of maize plants cultivated in direct planting was concentrated in the soil layer of 0 $10 \mathrm{~cm}$ with the application of lime to the soil surface [7]. The spatial distribution of roots with the highest concentrations near the plant and the surface is due to the morphology of the root system and the conditions generally more appropriate for the availability of nutrients, biological activity and aeration for root development in the upper soil layers. However, this study shows that the roots of maize not concentrated in the $0-10 \mathrm{~cm}$ layers of soil.

The leaf $\mathrm{Ca}, \mathrm{Mg}, \mathrm{Cu}, \mathrm{Fe}, \mathrm{Mn}$ and $\mathrm{Zn}$ maize showed no significant differences with the use of limestone with a particle size smaller than $0.30 \mathrm{~mm}$ applied to the surface of the soil (Tables 4 and 5). In this sense, the application of lime thinner on the ground surface did not impair the nutrition of the maize plant during the two years of cultivation. [7] reported that the use of re-liming the soil surface provides no significant influence on foliar concentrations of macro and micronutrients in maize agreeing with this present research.

The application of lime to the soil surface increased the Mg content in the leaves of maize [16], disagreeing

Table 4. Average values of nutrients in leaves of maize with application different particle size of limestone. Year: 2009.

\begin{tabular}{|c|c|c|c|c|c|c|c|c|c|c|c|c|}
\hline \multirow{3}{*}{$\begin{array}{c}\text { Particle Size } \\
\text { (mm) } \\
\text { Control }\end{array}$} & Ca & \multicolumn{3}{|c|}{ Mg } & \multicolumn{2}{|l|}{$\mathbf{C u}$} & \multicolumn{2}{|l|}{$\mathbf{F e}$} & \multicolumn{2}{|c|}{ Mn } & \multicolumn{2}{|c|}{$\mathbf{Z n}$} \\
\hline & \multicolumn{4}{|c|}{$\mathbf{g} \cdot \mathbf{k g}^{-1}$} & \multicolumn{8}{|c|}{$\mathbf{m g} \cdot \mathbf{k g}^{-1}$} \\
\hline & 3.75 & $a^{1}$ & 2.00 & $\mathrm{a}$ & 11.00 & $\mathrm{a}$ & 154.50 & $\mathrm{a}$ & 88.00 & $\mathrm{a}$ & 19.83 & a \\
\hline $0.30-0.20$ & 3.75 & $\mathrm{a}$ & 2.00 & $\mathrm{a}$ & 12.50 & $\mathrm{a}$ & 150.00 & $\mathrm{a}$ & 88.00 & $\mathrm{a}$ & 19.20 & $\mathrm{a}$ \\
\hline $0.20-0.10$ & 3.75 & $\mathrm{a}$ & 2.00 & a & 11.75 & $\mathrm{a}$ & 176.50 & $\mathrm{a}$ & 84.00 & $\mathrm{a}$ & 19.90 & a \\
\hline $0.10-0.05$ & 4.25 & $\mathrm{a}$ & 2.25 & $\mathrm{a}$ & 11.50 & $\mathrm{a}$ & 196.00 & $\mathrm{a}$ & 75.00 & $\mathrm{a}$ & 19.33 & $\mathrm{a}$ \\
\hline $0.05-0.01$ & 3.50 & $\mathrm{a}$ & 2.00 & $\mathrm{a}$ & 11.00 & $\mathrm{a}$ & 196.50 & $\mathrm{a}$ & 74.75 & $\mathrm{a}$ & 20.70 & $\mathrm{a}$ \\
\hline Average & 3.80 & & 2.05 & & 11.55 & & 174.70 & & 81.95 & & 19.79 & \\
\hline $\mathrm{CV}(\%)^{2}$ & 14.41 & & 14.41 & & 10.30 & & 24.20 & & 9.17 & & 7.33 & \\
\hline
\end{tabular}

${ }^{1}$ Values followed by lower case letters in the same column do not differ (Tukey test, $\mathrm{P}<0.05$ ); ${ }^{2} \mathrm{CV}$ : Coefficient of variation.

Table 5. Average values of nutrients in leaves of maize with application different particle size of limestone. Year: 2010.

\begin{tabular}{|c|c|c|c|c|c|c|c|c|c|c|c|c|}
\hline \multirow{3}{*}{$\begin{array}{c}\text { Particle Size } \\
\mathbf{( m m )} \\
\text { Control }\end{array}$} & Ca & \multicolumn{3}{|c|}{ Mg } & \multicolumn{2}{|c|}{$\mathrm{Cu}$} & \multicolumn{2}{|c|}{ Fe } & \multicolumn{2}{|c|}{ Mn } & \multicolumn{2}{|c|}{ Zn } \\
\hline & \multicolumn{4}{|c|}{$\mathbf{g} \cdot \mathbf{k g}^{-1}$} & \multicolumn{8}{|c|}{$\mathbf{m g} \cdot \mathbf{k g}^{-1}$} \\
\hline & 3.45 & $\mathrm{a}^{1}$ & 1.30 & $\mathrm{a}$ & 19.75 & $\mathrm{a}$ & 88.00 & $\mathrm{a}$ & 45.75 & $\mathrm{a}$ & 18.50 & $\mathrm{a}$ \\
\hline $0.30-0.20$ & 3.25 & $\mathrm{a}$ & 1.28 & $\mathrm{a}$ & 20.25 & $\mathrm{a}$ & 88.00 & $\mathrm{a}$ & 50.25 & $\mathrm{a}$ & 21.00 & $\mathrm{a}$ \\
\hline $0.20-0.10$ & 3.55 & $\mathrm{a}$ & 1.40 & $\mathrm{a}$ & 20.00 & $\mathrm{a}$ & 84.00 & $\mathrm{a}$ & 47.00 & $\mathrm{a}$ & 19.75 & $\mathrm{a}$ \\
\hline $0.10-0.05$ & 3.55 & $\mathrm{a}$ & 1.30 & $\mathrm{a}$ & 20.25 & $\mathrm{a}$ & 75.00 & $\mathrm{a}$ & 41.25 & $\mathrm{a}$ & 19.75 & $\mathrm{a}$ \\
\hline $0.05-0.01$ & 3.78 & $\mathrm{a}$ & 1.28 & $\mathrm{a}$ & 20.00 & $\mathrm{a}$ & 74.75 & $\mathrm{a}$ & 46.25 & $\mathrm{a}$ & 20.00 & $\mathrm{a}$ \\
\hline Average & 3.52 & & 1.31 & & 20.05 & & 81.95 & & 46.10 & & 19.80 & \\
\hline $\mathrm{CV}(\%)^{2}$ & 12.93 & & 12.93 & & 8.60 & & 9.17 & & 17.72 & & 14.35 & \\
\hline
\end{tabular}

${ }^{1}$ Values followed by lower case letters in the same column do not differ (Tukey test, $\mathrm{P}<0.05$ ); ${ }^{2} \mathrm{CV}$ : Coefficient of variation. 
with this research where this increase was not observed. Already, [17] reports that the levels of macro and micronutrients in maize leaves were not influenced by the modes of application of limestone, corporate, and superficially applied at planting and claims that this was due to the condition of adequate moisture and fertility level soil during the crop cycle, may be the possible causes of non-differentiation between treatments, preventing distinction cultivars exhibited tolerance to $\mathrm{Al}^{3+}$.

According [15] the use of liming on different doses of limestone with PRNT 85\% promoted the increase in the amount of $\mathrm{P}, \mathrm{Ca}, \mathrm{Mg}$ and $\mathrm{S}$ absorbed by maize plants. However, even using finely ground limestone with PRNT 100\% applied to the surface of the soil in this present study was not observed increase of macro and micronutrients in maize leaves in two consecutive years of cultivation. This result was not expected, because with the increased availability of nutrients in the soil by liming, increase up foliar nutrient contents. However, the use of limestone with particle size smaller than $0.30 \mathrm{~mm}$ across promoted a soil amendment and not concentrated in the surface layer allowing a chemical balance of nutrients in the soil and thus promoting adequate absorption of these nutrients.

The CREM represents the root length relative to its mass, the higher the value of this parameter are thinner roots. In this sense, the maize had fine roots in $10-20 \mathrm{~cm}$ soil layer with use of limestone particle size between 0.10 at $0.05 \mathrm{~mm}$. The fine roots are primarily responsible for absorbing water and nutrients from the soil by the plants. However, this reflected in the correlation between the maize root and leaf nutrient contents in leaf of this plant in the first year (Tables 6 and 7).

The levels of foliar Ca in maize significantly correlated with $\mathrm{Mg}$ and $\mathrm{Zn}$ in 2009. Just CRM maize correlated with the concentration of Mn in leaves of maize. ARVs, ARM, CRV, CRM, CRM, MRV, MRS, CREM attributes correlated with each other means that year. The reviews root attributes not correlated with grain yield of maize in the first year due to the application of limestone with less than $0.30 \mathrm{~mm}$ on the surface of the soil particle sizes.

The Ca content in maize leaf did not correlate significantly with Mg in the second year. This year, there was no correlation between root attributes of maize and the levels of macro and micronutrients in the leaves of maize and also for the production of maize grains due to the application of finely ground limestone applied superfi-

Table 6. Pearson correlation between $\mathrm{Ca}, \mathrm{Mg}, \mathrm{Cu}, \mathrm{Fe}, \mathrm{Mn}$ and $\mathrm{Zn}$ in leaves of maize, root attributes and grain yield of maize with application different particle sizes of limestone. Year: 2009.

\begin{tabular}{ccccccccccccccc}
\hline Variables & Ca & Mg & Cu & Fe & Mn & Zn & ARV $^{(1)}$ & ARM & CRV & CRM & MRV & MRS & CREM Grainyield \\
\hline Ca & 1 & $0.54^{* *}$ & -0.07 & 0.11 & -0.06 & $-0.69^{* *}$ & -0.03 & -0.02 & 0.01 & -0.06 & 0.03 & -0.05 & 0.01 & -0.20 \\
Mg & $0.54^{* * *}$ & 1 & 0.09 & $0.46^{* *}$ & -0.30 & -0.33 & 0.11 & 0.09 & 0.14 & -0.01 & 0.13 & -0.03 & 0.09 & -0.16 \\
Cu & -0.07 & 0.09 & 1 & 0.03 & 0.42 & 0.10 & 0.11 & 0.13 & 0.15 & -0.11 & 0.17 & -0.02 & 0.21 & -0.16 \\
Fe & 0.11 & $0.46^{* *}$ & 0.03 & 1 & -0.35 & 0.03 & -0.01 & -0.13 & 0.01 & 0.11 & -0.08 & -0.06 & -0.16 & -0.32 \\
Mn & -0.06 & -0.30 & 0.42 & -0.35 & 1 & -0.10 & -0.35 & -0.28 & -0.35 & $0.46^{* *}$ & -0.30 & -0.33 & -0.22 & 0.18 \\
Zn & $-0.69^{* *}$ & -0.33 & 0.10 & 0.03 & -0.10 & 1 & 0.07 & 0.03 & 0.09 & 0.05 & 0.05 & 0.08 & 0.08 & -0.02 \\
ARV & -0.03 & 0.11 & 0.11 & -0.01 & -0.35 & 0.07 & 1 & $0.98^{* *}$ & $0.97^{* *}$ & $0.62^{* *}$ & $0.96^{* *}$ & $0.72^{* *}$ & $0.89^{* *}$ & -0.41 \\
ARM & -0.02 & 0.09 & 0.13 & -0.13 & -0.28 & 0.03 & $0.98^{* *}$ & 1 & $0.94^{* *}$ & $0.56^{* *}$ & $0.96^{* *}$ & $0.72^{* *}$ & $0.92^{* *}$ & -0.41 \\
CRV & 0.01 & 0.14 & 0.15 & 0.01 & -0.35 & 0.09 & $0.97^{* *}$ & $0.94^{* *}$ & 1 & $0.66^{* *}$ & $0.98^{* *}$ & $0.70^{* *}$ & $0.89^{* *}$ & -0.37 \\
CRM & -0.06 & -0.01 & -0.11 & 0.11 & $0.46^{* *}$ & 0.05 & $0.62^{* *}$ & $0.56^{* *}$ & $0.66^{* *}$ & 1 & $0.61^{* *}$ & $0.87^{* *}$ & $0.59^{* *}$ & -0.12 \\
MRV & 0.03 & 0.13 & 0.17 & -0.08 & -0.30 & 0.05 & $0.96^{* *}$ & $0.96^{* *}$ & $0.98^{* *}$ & $0.61^{* *}$ & 1 & $0.71^{* *}$ & $0.94^{* *}$ & -0.37 \\
MRS & -0.05 & -0.03 & -0.02 & -0.06 & -0.33 & 0.08 & $0.72^{* *}$ & $0.72^{* *}$ & $0.70^{* *}$ & $0.87^{* *}$ & $0.71^{* *}$ & 1 & 0.74 & -0.34 \\
CREM & 0.01 & 0.09 & 0.21 & -0.16 & -0.22 & 0.08 & $0.89^{* *}$ & $0.92^{* *}$ & $0.89^{* *}$ & $0.59^{* *}$ & $0.94^{* *}$ & $0.74^{* *}$ & 1 & -0.36 \\
Grainyield & -0.20 & -0.16 & -0.16 & -0.32 & 0.18 & -0.02 & -0.41 & -0.41 & -0.37 & -0.12 & -0.37 & -0.34 & -0.36 & 1 \\
\hline
\end{tabular}

${ }^{*}$ significant at $1 \%$ for test $\mathrm{F} ;{ }^{* *}$ significant at the $5 \%$ for test $\mathrm{F} ;{ }^{(1)} \mathrm{ARV}$-root area based on the volume of soil sampled; ARM-root area based on soil mass sampled; CRV - root length based on the volume of soil sampled; CRM—root length based on soil mass sampled; MRV-root mass based on the volume of soil sampled; MRS—dry root mass-based soil sampled; CREM—root length per root mass based on the mass of the sampled soil. 
cially in the soil. However, the root attributes evaluated were significantly correlated.

Limestone with particle sizes less than $0.30 \mathrm{~mm}$ at the soil surface did not influence the production of maize crops in 2008/2009 and 2009/2010, only differed from the results of the area without liming. Thus, the grain yield of maize was not harmed by the changes of chemical properties of soil and foliar nutrient concentrations occurred by the use of limestone with less than $0.30 \mathrm{~mm}$ particles (Table 8 ).

No-tillage (NT) allows the roots to deepen the soil through a continuous network of pores formed by senescent roots and the microorganisms [18]. However, the NT consolidated moving machinery increasing resistance to soil penetration [19] and the application of fertilizers and the soil surface does not allow the deepening of

Table 7. Pearson correlation between $\mathrm{Ca}, \mathrm{Mg}, \mathrm{Cu}, \mathrm{Fe}, \mathrm{Mn}$ and $\mathrm{Zn}$ in leaves of maize, root attributes and grain yield of maize with application different particle sizes of limestone. Year: 2010.

\begin{tabular}{ccccccccccccccc}
\hline Variables & Ca & Mg & Cu & Fe & Mn & Zn & ARV & ARM & CRV & CRM & MRV & MRS & CREM & Grainyield \\
\hline Ca & 1 & 0.34 & 0.20 & $0.67^{* *}$ & $-0.55^{* *}$ & 0.31 & 0.01 & -0.04 & -0.02 & 0.07 & -0.06 & 0.04 & -0.06 & -0.44 \\
Mg & 0.34 & 1 & -0.26 & 0.05 & -0.24 & 0.04 & 0.17 & 0.10 & 0.23 & 0.24 & 0.17 & 0.01 & 0.06 & -0.57 \\
Cu & 0.20 & -0.26 & 1 & 0.35 & 0.23 & 0.21 & 0.02 & 0.03 & -0.14 & -0.40 & -0.12 & -0.30 & -0.12 & 0.10 \\
Fe & $0.67^{* *}$ & 0.05 & 0.35 & 1 & -0.21 & 0.18 & 0.16 & 0.17 & 0.08 & 0.12 & 0.08 & 0.24 & 0.10 & 0.14 \\
Mn & $-0.55^{* *}$ & -0.24 & 0.23 & -0.21 & 1 & -0.10 & 0.00 & 0.01 & -0.04 & -0.08 & -0.03 & -0.13 & -0.15 & 0.56 \\
Zn & 0.31 & 0.04 & 0.21 & 0.18 & -0.10 & 1 & -0.10 & -0.13 & -0.16 & -0.02 & -0.18 & -0.11 & -0.20 & -0.01 \\
ARV & 0.01 & 0.17 & 0.02 & 0.16 & 0.00 & -0.10 & 1 & $0.98^{* *}$ & $0.97^{* *}$ & $0.62^{* *}$ & $0.96^{* *}$ & $0.72^{* *}$ & $0.89^{* *}$ & -0.08 \\
ARM & -0.04 & 0.10 & 0.03 & 0.17 & 0.01 & -0.13 & $0.98^{* *}$ & 1 & $0.94^{* *}$ & $0.56^{* *}$ & $0.96^{* *}$ & $0.72^{* *}$ & $0.92^{* *}$ & 0.00 \\
CRV & -0.02 & 0.23 & -0.14 & 0.08 & -0.04 & -0.16 & $0.97^{* *}$ & $0.94^{* *}$ & 1 & $0.66^{* *}$ & $0.98^{* *}$ & $0.70^{* *}$ & $0.89^{* *}$ & -0.13 \\
CRM & 0.07 & 0.24 & -0.40 & 0.12 & -0.08 & -0.02 & $0.62^{* *}$ & $0.56^{* *}$ & $0.66^{* *}$ & 1 & $0.61^{* *}$ & $0.87^{* *}$ & $0.59^{* *}$ & -0.22 \\
MRV & -0.06 & 0.17 & -0.12 & 0.08 & -0.03 & -0.18 & $0.96^{* *}$ & $0.96^{* *}$ & $0.98^{* *}$ & $0.61^{* *}$ & 1 & $0.71^{* *}$ & $0.94^{* *}$ & -0.07 \\
MRS & 0.04 & 0.01 & -0.30 & 0.24 & -0.13 & -0.11 & $0.72^{* *}$ & $0.72^{* *}$ & $0.70^{* *}$ & $0.87^{* *}$ & $0.71^{* *}$ & 1 & 0.74 & 0.03 \\
CREM & -0.06 & 0.06 & -0.12 & 0.10 & -0.15 & -0.20 & $0.89^{* *}$ & $0.92^{* *}$ & $0.89^{* *}$ & $0.59^{* *}$ & $0.94^{* *}$ & $0.74^{* *}$ & 1 & -0.09 \\
Grainyield & -0.44 & -0.57 & 0.10 & 0.14 & 0.56 & -0.01 & -0.08 & 0.00 & -0.13 & -0.22 & -0.07 & 0.03 & -0.09 & 1 \\
\hline
\end{tabular}

${ }^{*}$ significant at $1 \%$ for test $\mathrm{F} ;{ }^{* *}$ significant at the $5 \%$ for test $\mathrm{F} ;{ }^{(1)} \mathrm{ARV}$-root area based on the volume of soil sampled; ARM-root area based on soil mass sampled; CRV - root length based on the volume of soil sampled; CRM—root length based on soil mass sampled; MRV-root mass based on the volume of soil sampled; MRS—dry root mass-based soil sampled; CREM—root length per root mass based on the mass of the sampled soil.

Table 8. Grain yield of maize (Mg·ha ${ }^{-1}$ ) with application different particle size of lime, in two year (2009 and 2010).

\begin{tabular}{|c|c|c|c|c|c|c|c|c|}
\hline \multirow{3}{*}{$\begin{array}{c}\text { Particle Size } \\
\text { (mm) }\end{array}$} & \multicolumn{5}{|c|}{ Grain yield of Maize } & & \multirow{3}{*}{ Average } & \multirow{3}{*}{ CV (\%) } \\
\hline & \multicolumn{4}{|c|}{ Mg $\cdot h a^{-1}$} & & & & \\
\hline & 2009 & & & 2010 & & & & \\
\hline Control & 4.16 & $\mathrm{~b}^{1}$ & A & 5.23 & $\mathrm{~b}$ & A & 4.69 & 38.38 \\
\hline $0.30-0.20$ & 8.77 & a & A & 7.45 & $\mathrm{a}$ & B & 8.11 & 18.29 \\
\hline $0.20-0.10$ & 8.44 & $\mathrm{ab}$ & A & 8.13 & $\mathrm{a}$ & B & 8.31 & 19.35 \\
\hline $0.10-0.05$ & 8.06 & $\mathrm{~b}$ & $\mathrm{~B}$ & 7.39 & $\mathrm{a}$ & A & 7.95 & 15.51 \\
\hline $0.05-0.01$ & 7.55 & $\mathrm{~b}$ & $\mathrm{~B}$ & 8.02 & $\mathrm{a}$ & A & 7.78 & 14.2 \\
\hline Average & 8.51 & & A & 7.33 & & A & & \\
\hline $\mathrm{CV}(\%)^{2}$ & 15.8 & & & 14.7 & & & & \\
\hline
\end{tabular}

${ }^{1}$ Means followed by the same letter in lowercase in columns and uppercase in the row do not differ by Tukey test (P < 0.05); ${ }^{2} \mathrm{C} . \mathrm{V} .:$ Coefficient of variation. 
maize roots for more subsurface layers [20]. The SPD has not yet consolidated along with the use of limestone particle size from $0.30 \mathrm{~mm}$ to $0.20 \mathrm{~mm}$ applied to the soil surface promoted elongation of roots into deeper soil layers.

The liming had a positive effect on maize root growth, but the average radius of the roots was not altered [19]. Under one view, the average root radius was smaller with surface application of limestone particle size between $0.10 \mathrm{~mm}$ to $0.05 \mathrm{~mm}$ in $10-20 \mathrm{~cm}$ soil depth.

The different particle sizes of limestone altered the root distribution of maize plant in the $0-20 \mathrm{~cm}$ soil depth in the two years studied. Accordingly, [16] also observed that the incorporation of lime did not favor the growth of the root system of maize compared to surface application using limestone with $100 \%$ PRNT. Since [21] found that the incorporation of lime in the rate of $6.8 \mathrm{t} \cdot \mathrm{ha}^{-1}$ in a dystrophic Ultisol promoted root growth of maize to $0.45 \mathrm{~m}$ depth in the soil, compared to liming. Even without incorporating limestone with a particle size between $0.30 \mathrm{~mm}$ and $0.20 \mathrm{~mm}$ caused greater root development in $20 \mathrm{a} 40 \mathrm{~cm}$ soil layer in the second year.

The auger method associated with the processing method roots was effective in the description of the parameters rooting of maize plants using limestone in different particle sizes. [5] compared the methods of the auger, volumetric cylinder and image processing method in maize root distribution in the soil profile and found that the auger constituted the most suitable for a simple, quickly and inexpensively. However, the method of processing images presented as a very powerful tool for the detailed study of the root system can also be applied to various areas within the agronomic science.

\section{Conclusion}

The limestone with a particle size between $0.10 \mathrm{~mm}$ and $0.05 \mathrm{~mm}$ applied to the soil surface NT promotes the development of fine roots in $10-20 \mathrm{~cm}$ depth. The elongation of maize roots on $20-40 \mathrm{~cm}$ depth is promoted by the use limestone with particle size between $0.30 \mathrm{~mm}$ and $0.20 \mathrm{~mm}$ applied to the soil surface in NT. The leaf $\mathrm{Ca}, \mathrm{Mg}, \mathrm{Cu}, \mathrm{Fe}, \mathrm{Mn}$ and $\mathrm{Zn}$ in maize are not affected by limestone with a particle size of $0.30 \mathrm{~mm}$ below the soil surface in NT. The root development promoted by surface application of finely ground limestone does not reflect the effect of $\mathrm{Ca}$ and $\mathrm{Mg}$ absorption and grain yield of maize.

\section{References}

[1] Alleoni, L.R.F., Cambri, M.A. and Caires, E.F. (2005) Atributos Químicos de um Latossolo de Cerrado sob Plantio Direto, de Acordo com Doses e Formas de Aplicação de Calcário. Revista Brasileira de Ciência do Solo, 29, 923-934. http://dx.doi.org/10.1590/S0100-06832005000600010

[2] Kaminski, J., Santos, D.R., Gatiboni, L.C., Brunettoand, G. and Silva, L.S. (2005) Eficiência da Calagem Superficial e Incorporada Precedendo o Sistema de Plantio Direto em um Argissolo sob Pastagem Natural. Revista Brasileira de Ciência do Solo, 29, 573-580. http://dx.doi.org/10.1590/S0100-06832005000400010

[3] Caires, E.F., Banzatto, D.A. and Fonseca, A.F. (2000) Calagem na Superfície em Sistema de Plantio Direto. Revista Brasileira de Ciência do Solo, 24, 161-169.

[4] Rylter, R.M. (1997) Fine Root Production and Carbon and Nitrogen Allocation in Basket Willows. Ph.D. Dissertation, Swedish University of Agricultural Science, Uppsala,

[5] Fante-jrand, L. and Reichardt, K. (1994) Distribuição do Sistema Radicular de Milho em Terra Roxa Estruturada Latossólica: I. Comparação de Metodologias. Scientia Agricola, 53, 513-518.

[6] Jansen, S., Broadley, M.R., Robbrecht, E. and Smets, E. (2002) Aluminum Hyperaccumulation in Angiosperms: A Review of Its Phylogenetic Significance. The Botanical Review, 68, 235-269. http://dx.doi.org/10.1663/0006-8101(2002)068[0235:AHIAAR]2.0.CO;2

[7] Caires, E.F. Barth, G., Garbuio, F.J. and Kusman, M.T. (2002) Correção da Acidez do Solo, Crescimento Radicular e Nutrição do Milho de Acordo com a Calagem na Superfície em Sistema Plantio Direto. Revista Brasileira de Ciência do solo, 26, 1011-1022.

[8] Cerettaand, C.A. and Fries, M.R. (1998) Adubação Nitrogenada no Sistema Plantio Direto. In: Neumberg, N.J., Ed, Conceitos e Fundamentos do Sistema Plantio Direto, Sociedade Brasileira de Ciência do Solo, Lages, 111-120.

[9] Embrapa (2006) Sistema Brasileiro de Classificação de Solos (SiBCS) 2nd Edition, CNPS.

[10] Bohm, W. (1979) Methods of Studing Root Systems. In: Durham, W.D.B., Athens, F.G., Wurzburg, O.L.L. and Oak Ridge, J.S.O., Eds., Ecological Studies: Analysis and Synthesis, Springer, New York, 98-188.

[11] Jorge, L.A.C. and Crestana, S. (1996) SIARCS 3.0: Novo Aplicativo para Análise de Imagens Digitais Aplicado a 
Ciência do Solo. CLACSCongresso Latino Americano de Ciência do Solo, Águas de Lindóia, 1-5.

[12] Embrapa, (2009) Manual de Análises Químicas de Solos, Plantas e Fertilizantes. Embrapa Informação Tecnológica, Brasília.

[13] SAS Institute, (1999) SAS/STAT User’s guide, Version 8. SAS Institute, Cary.

[14] Costa, N.H.A.D., Seraphin, J.C. and Zimmermann, F.J.P. (2002) Novo Método de Classificação de Coeficientes de Variação para a Cultura do Arroz de Terras Altas. Pesquisa Agropecuária Brasileira, 37, 243-249. http://dx.doi.org/10.1590/S0100-204X2002000300003

[15] Tissi, J.A., Caires, E.F. and Pauletti, V. (2004) Efeitos da Calagem em Semeadura Direta de Milho. Bragantia, 63, 405-413. http://dx.doi.org/10.1590/S0100-204X2002000300003

[16] Caires, E.F., Kusman, M.T., Barth, G., Garbuio, F.J. and Padilha, J.M. (2004) Alterações Químicas do Solo e Resposta do Milho a Calagem e Aplicação de Gesso. Revista Brasileira de Ciência do Solo, 28, 125-136. http://dx.doi.org/10.1590/S0100-06832004000100013

[17] Pires, F.R., Souza, C.M., Queiroz, D.M., Miranda, G.V.and Galvão, J.C.C. (2003) Alteração de Atributos Químicos do Solo e Estado Nutricional e Características Agronômicas de Plantas de Milho, Considerando as Modalidades de Calagem em Plantio Direto. Revista Brasileira de Ciência do Solo, 27, 121-131. http://dx.doi.org/10.1590/S0100-06832003000100013

[18] Eltz, F.V.L.F., Peixoto, R.T.G. and Jaster, F. (1989) Efeitos de Sistemas de Preparo do Solo nas Propriedades Físicas e Químicas de um Latossolo Bruno álico. Revista Brasileira de Ciência do Solo, 13, 259-267.

[19] Rosolem, C.A., Vale, L.S.R., Grassi Filho, H. and Moraes, M.H. (1994) Sistema Radicular e Nutrição do Milho em Função da Calagem e da Compactação do Solo. Revista Brasileira de Ciência do Solo, 18, 491-497.

[20] Kluthcouski, J., Fancelli, A.L., Dourado-Neto, D., Ribeiro, C.M. and Ferrraro, L.A. (2000) Manejo do Solo e o Rendimento de Soja, Milho, Feijão e Arroz em Plantio Direto. Scientia Agricola, 57, 97-104. http://dx.doi.org/10.1590/S0103-90162000000100016

[21] Leite, G.H.M.N., Eltz, F.V.L.F., Amado, T.J.C. and Cogo, N. P. (2006) Atributos Químicos e Perfil de Enraizamento de Milho Influenciados pela Calagem em Semeadura Direta. Revista Brasileira de Ciência do Solo, 30, 685-693. http://dx.doi.org/10.1590/S0100-06832006000400009 